Marquette University

e-Publications@Marquette

$10-1-2017$

\title{
Do College Admissions Counselors Discriminate? Evidence from a Correspondence-Based Field Experiment
}

Andrew Hanson

Marquette University, andrew.r.hanson@marquette.edu

Accepted version. Economics of Education Review, Vol. 60 (October 2017): 86-96. DOI. (C) 2017 Elsevier. Used with permission. 
Marquette University

\section{e-Publications@Marquette}

\section{Economics Faculty Research and Publications/Department of Economics}

This paper is NOT THE PUBLISHED VERSION; but the author's final, peer-reviewed manuscript. The published version may be accessed by following the link in the citation below.

Economics of Education Review, Vol. 60 (2017): 86-96. DOI. This article is (C) Elsevier and permission has been granted for this version to appear in e-Publications@Marquette. Elsevier does not grant permission for this article to be further copied/distributed or hosted elsewhere without the express permission from Elsevier.

\section{Do College Admissions Counselors Discriminate? Evidence from a Correspondence-Based Field Experiment}

Andrew Hanson

Department of Economics, Marquette University, Milwaukee WI

\section{Abstract}

I design and implement a correspondence based field experiment to test for race and gender discrimination among college admissions counselors in the student information gathering stage. The experiment uses names to identify student race and gender, and student grade, SAT score, and writing differences to reflect varying levels of applicant quality. I find that counselors do not respond differently by race in most cases, but there are measurable differences in response/non-response and in the type of correspondence sent that favor female students. I also find that the quality of the student induces large differences in the type of response.

Keywords

College application, Discrimination, Field experiment, Race, Gender 


\section{Introduction}

Stark differences exist in postsecondary school enrollment across gender and race groups. While $66.6 \%$ of whites age 18-24 report either having attended, being currently enrolled, or already completed college, only $51.6 \%$ of African American young adults report the same. The difference between genders is nearly as stark, with $66.2 \%$ of females age 18-24 reporting either having attended, being currently enrolled, or already completed college, and only $54.9 \%$ of male young adults reporting the same. 1 College completion rates show an even bigger racial divide, $\underline{-}$ with $61.5 \%$ of first-time postsecondary attending whites completing their degree within 6 years, versus only $39.6 \%$ of African Americans. - The gender divide is considerably more narrow for college completion rates, with $60.6 \%$ of female firsttime postsecondary attendees finishing a degree within 6 years, versus $55.5 \%$ of males.

Explanations for the gender and racial gap in postsecondary enrollment and completion are wide and varied, with possible contributing factors including: pre-existing group characteristic differences (including income, preparation, prior schooling, etc.), application and search differences, institutional experience differences, societal events, social norms, and policy impacts. ${ }^{4}$ Hoxby and Avery (2013) show that the college application stage is critical in explaining the observed divergence in where students with similar achievement levels, but different incomes, end up attending college. Holland (2014) reviews the current state of the literature on the differences that exist between whites and minorities in the college search and application process, and highlights the literature's focus on the student-side of the process. Goldin, Katz and Kuziemko (2006) provide an overview of historical gender differences in college attendance and outcomes as well as an investigation into the cause of the gap using observational data across several decades. The literature on the institution-side of the admissions process largely focuses on how affirmative action policies impact admissions, enrollment, and completion differences between races. $\frac{5}{A}$ previously unexplored component that may contribute to gender and racial gaps in college attendance and degree completion is the potential for students to face differential treatment in the search and information gathering process.

I examine differential treatment by college admissions counselors according to a student's race, gender, and application quality using a correspondence field experiment. Communication with admission counselors is of particular interest in the college application process as previous work shows that students generally do not apply to enough colleges, tend to under-apply in terms of quality (Avery, Howell \& Page, 2014), but respond strongly to small costs in the application process (Smith, Hurwitz \& Howell, 2014). Interactions with admissions counselors could introduce small differences in the cost associated with the application process by providing (or not providing) information, easing (or raising) admissions concerns, offering (or withholding) advice on a successful application, or changing the psychological costs of submitting an application (encouraging or discouraging the potential student).

Differential treatment by admissions counselors could change application behavior and thus enrollment behavior as the number of applications a student completes causally affects enrollment (Smith, 2014). Differential treatment of minority students and between genders in the information gathering stage may have a compounding effect on applications and enrollment that ultimately 
manifest in other disparities. Furthermore, there is evidence to suggest that counseling interventions influence where prospective college students choose to apply (Avery, 2010), highlighting the importance of positive interventions in the college application process. In addition, any differential treatment found in a simple information-gathering exercise may be representative of a larger problem among admissions counselors that could lead to more severe differences in treatment in the application process.

The two leading explanations on the source of discrimination are that it is based on individual preference (Becker, 1957) or that it is based on statistical differences in-group characteristics (Phelps, 1972). Either explanation could potentially be important in the college admissions setting. Taste-based discrimination may happen in any setting where individuals have some leeway in expressing personal preferences that are not bound by a profit motive- information gathering by students may well be such a case. Statistical discrimination may occur if counselors believe that one group represents higher quality students on average over another, rather than considering the marginal applicant. Either source of discrimination may be mitigated by motivations at the University level to encourage applications by all students, as lower acceptance rates generally improve institution rankings (and are driven by more applications), but how well this translates to individual counselor motivation is a function of incentives in place at individual institutions.

The correspondence field experiment is set up to examine differential treatment by college admissions counselors at the information gathering stage of a student's application process. To do this, I contact admissions counselors through e-mail, revealing student gender and race through the name associated with the inquiry, and student quality through the text of the correspondence (using SAT score, grade information, and the style of communication). Similar to prominent labor and housing market studies, the names in the study that represent race come from birth certificate data. The experiment itself is a matched-pair experiment, with pairs of correspondence sent to counselors matched by race.

Differences in gender and applicant quality are not matched by pair, but instead randomly assigned throughout the subject population.

Analyzing the results of the field experiment for the full sample of 5036 counselors $(10,072$ e-mails), I find that counselors do not treat potential students differently by race in either the response/nonresponse decision, or in the content of responses. There are is some evidence of differential treatment by race in sub-samples of the data, but these offset in the full sample. I find evidence that counselors favor women over men- both in terms of response/non-response and in how they respond to the correspondence. Counselors are more likely to use a polite greeting and positive language when responding to female names in the experiment than they are when responding to males. Interacting treatment with counselor and institution characteristics, I find that female counselors are more likely to respond to female names, and that African Americans are less likely to receive a response from African American counselors and at higher ranked institutions. I also find large differences in the text of counselor responses to student quality - with counselors favoring higher quality students.

The remainder of the paper begins by outlining the design of the field experiment. The third section of the paper discusses the sample of counselors in the experiment and the data generated through the experiment, while section four presents results. Section five offers robustness checks of the primary results, and the final section of the paper offers concluding comments. 


\section{Experiment design}

The experiment is designed using correspondence between prospective students and university admissions counselors. Correspondence occurs through e-mail and is designed to test if applicant gender, race, or student quality influence if and how counselors respond to prospective students. Counselors receive race and gender signals through the name associated with a student inquiry. The text of emails, inclusion of grade point and SAT information, and the distribution of SAT and grade information all vary to represent different degrees of student quality.

The design of the experiment is "within subjects" for race of the students, and "between subjects" for the gender and quality of students. This means that each admissions counselor receives two e-mail inquiries, one from an African American, and another from a white prospective student. Inquiries sent to counselors are randomly assigned from the same gender group and quality group. Sending two emails per counselor allows for counselor fixed effects in measuring racial discrimination.

Randomization across a large number of counselors ensures that gender and quality differences are not correlated with other characteristics of the student or subject characteristics. Table 1 details the various pairs of e-mail inquiries a counselor in the experiment may receive.

Table 1. Within subjects e-mail possibilities.

First sender

Black Male Name, High Quality Text, Includes GPA and White Male Name, High Quality Text, Includes GPA and SAT

White Male Name, High Quality Text, Includes GPA and Black Male Name, High Quality Text, Includes GPA and SAT

Black Female Name, High Quality Text, Includes GPA and SAT

White Female Name, High Quality Text, Includes GPA and SAT

Black Male Name, Low Quality Text, Includes GPA and SAT

White Male Name, Low Quality Text, Includes GPA and SAT

Black Female Name, Low Quality Text, Includes GPA and SAT

White Female Name, Low Quality Text, Includes GPA and SAT

Black Male Name, Low Quality Text, No GPA or SAT

White Male Name, Low Quality Text, No GPA or SAT

Black Female Name, Low Quality Text, No GPA or SAT

White Female Name, Low Quality Text, No GPA or SAT
SAT

White Female Name, High Quality Text, Includes GPA and SAT

Black Female Name, High Quality Text, Includes GPA and SAT

White Male Name, Low Quality Text, Includes GPA and SAT

Black Male Name, Low Quality Text, Includes GPA and SAT

White Female Name, Low Quality Text, Includes GPA and SAT

Black Female Name, Low Quality Text, Includes GPA and SAT

White Male Name, Low Quality Text, No GPA or SAT Black Male Name, Low Quality Text, No GPA or SAT White Female Name, Low Quality Text, No GPA or SAT

Black Female Name, Low Quality Text, No GPA or SAT

The use of names to identify race and gender in correspondence discrimination experiments began with Neumark (1996) ${ }^{6}$ and continued with Bertrand and Mullainathan (2004), both papers use resumes in a field experiment measuring employer discrimination. ${ }^{7}$ Ahmed and Hammarstedt (2008), Carpusor 
and Loges (2006), Ewens, Tomlin and Wang (2014), Hanson and Hawley (2011), Hanson and Santas (2014) and Hanson, Hawley, Martin and Liu (2016) are recent examples using the correspondencebased communication in housing and mortgage markets. Nunley, Owens and Stephen Howard (2011) is an excellent example of using names to identify race of sellers and measure discrimination in product markets. Field experiments that rely on the use of names to reveal gender, race, or in some cases social class in education or human capital attainment have to date focused on testing for bias in grading, examples include: Hanna and Linden (2012), Hinnerich, Höglin and Johannesson (2015), Sprietsma (2011) and Feld, Salamanca, Hamermesh (2015). ${ }^{8}$ Holzer and Ludwig (2003) provides a general discussion on the usefulness of the audit method in the education field, while Riach and Rich (2002) offer a comprehensive overview of discrimination field experiments across a range of markets and interactions.

Correspondence-style experiments typically rely on birth certificate data to identify names that are unique to a single gender/race combination. The source for names in this experiment is the $1990 \mathrm{New}$ York City Department of Health and Human Hygiene birth certificate data. Table 2 shows the names identifying race and gender in the experiment, along with a set of summary statistics describing their popularity and use in the experiment. The names in the experiment represent three criteria: identification with only one race and gender, being secular, and being relatively more popular than other names within a gender-race type. $\stackrel{9}{ }$ All names in the data have a probability of 1 for being associated with a given race/gender combination in the birth certificate data. $\underline{10}$ Most names are between the 30th and 70th most popular for their given race/gender combination, reflecting the fact that many names that are popular across races are more popular than the names on the list. The national popularity column shows how popular the names in the experiment are among all babies born in the United States in 1990. This column reveals that the white names in the experiment are more popular than the African American names in the experiment, a function of the population distribution across races. The final two columns of Table 2 show the frequency and what percentage of total emails each name represents in the experiment. Each name represents approximately $5 \%$ of e-mail inquiries in the experiment, with small deviations as a result of random assignment.

Table 2. Names used to identify student race.

\begin{tabular}{|c|c|c|c|c|c|}
\hline $\begin{array}{cc}P & P \\
\text { iender| Name) } & \text { (Race| Name) }\end{array}$ & $\begin{array}{l}\text { Popularity } \\
\text { Rank within } \\
\text { Race and } \\
\text { Gender }\end{array}$ & $\begin{array}{c}\text { Popularity } \\
\text { Rank within } \\
\text { Gender }\end{array}$ & $\begin{array}{l}\text { National } \\
\text { Popularity }\end{array}$ & $\begin{array}{l}\text { Frequency of } \\
\text { Occurrence in } \\
\text { Experiment }\end{array}$ & $\begin{array}{c}\text { Percent } \\
\text { of E- } \\
\text { mails }\end{array}$ \\
\hline
\end{tabular}

African American

Male

\begin{tabular}{|c|c|c|c|c|c|c|c|}
\hline $\begin{array}{c}\text { Darnell } \\
\text { Robinson }\end{array}$ & 1 & 1 & 60 & 154 & 353 & 518 & $5.14 \%$ \\
\hline $\begin{array}{l}\text { Dwayne } \\
\text { Williams }\end{array}$ & 1 & 1 & 55 & 144 & 307 & 554 & $5.50 \%$ \\
\hline $\begin{array}{c}\text { Jamal } \\
\text { Washington }\end{array}$ & 1 & 1 & 29 & 109 & 247 & 488 & $4.85 \%$ \\
\hline $\begin{array}{l}\text { Kadeem } \\
\text { Jackson }\end{array}$ & 1 & 1 & 35 & 120 & 536 & 477 & $4.74 \%$ \\
\hline
\end{tabular}




\begin{tabular}{|c|c|c|c|c|c|c|c|}
\hline & $\begin{array}{c}P \\
\text { (Gender|Name) }\end{array}$ & $\begin{array}{c}P \\
\text { (Race } \mid \text { Name) }\end{array}$ & $\begin{array}{c}\text { Popularity } \\
\text { Rank within } \\
\text { Race and } \\
\text { Gender }\end{array}$ & $\begin{array}{c}\text { Popularity } \\
\text { Rank within } \\
\text { Gender }\end{array}$ & $\begin{array}{l}\text { National } \\
\text { Popularity }\end{array}$ & $\begin{array}{c}\text { Frequency of } \\
\text { Occurrence in } \\
\text { Experiment }\end{array}$ & $\begin{array}{c}\text { Percent } \\
\text { of E- } \\
\text { mails }\end{array}$ \\
\hline $\begin{array}{l}\text { Tyrone } \\
\text { Smith }\end{array}$ & 1 & 1 & 63 & 171 & 260 & 482 & $4.79 \%$ \\
\hline \multicolumn{8}{|l|}{ Female } \\
\hline $\begin{array}{c}\text { Asia } \\
\text { Robinson }\end{array}$ & 1 & 1 & 35 & 170 & 299 & 558 & $5.54 \%$ \\
\hline $\begin{array}{c}\text { Chantel } \\
\text { Smith }\end{array}$ & 1 & 1 & 37 & 178 & 362 & 539 & $5.35 \%$ \\
\hline $\begin{array}{l}\text { Latoya } \\
\text { Williams }\end{array}$ & 1 & 1 & 30 & 154 & 254 & 483 & $4.80 \%$ \\
\hline $\begin{array}{c}\text { Ebony } \\
\text { Jackson }\end{array}$ & 1 & 1 & 20 (tie) & 109 (tie) & 187 & 503 & $4.99 \%$ \\
\hline $\begin{array}{c}\text { Shaniqua } \\
\text { Washington }\end{array}$ & 1 & 1 & 20 (tie) & 109 (tie) & 327 & 434 & $4.31 \%$ \\
\hline \multicolumn{8}{|l|}{ White } \\
\hline \multicolumn{8}{|l|}{ Male } \\
\hline Ethan Olson & 1 & 1 & 80 & 232 & 58 & 521 & $5.17 \%$ \\
\hline Dylan Larson & 1 & 1 & 65 & 174 & 83 & 496 & $4.92 \%$ \\
\hline $\begin{array}{l}\text { Maxwell } \\
\text { Smith }\end{array}$ & 1 & 1 & 86 & 246 & 188 & 508 & $5.04 \%$ \\
\hline $\begin{array}{l}\text { Brendan } \\
\text { Carlson }\end{array}$ & 1 & 1 & 64 & 173 & 155 & 520 & $5.16 \%$ \\
\hline $\begin{array}{l}\text { Zachary } \\
\text { Schmidt }\end{array}$ & 1 & 1 & 27 & 67 & 22 & 474 & $4.71 \%$ \\
\hline \multicolumn{8}{|l|}{ Female } \\
\hline Erin Carlson & 1 & 1 & 44 & 116 & 43 & 544 & $5.40 \%$ \\
\hline $\begin{array}{l}\text { Marissa } \\
\text { Smith }\end{array}$ & 1 & 1 & 67 & 155 & 87 & 503 & $4.99 \%$ \\
\hline $\begin{array}{l}\text { Kathryn } \\
\text { Olson-a }\end{array}$ & 1 & 1 & 59 & 142 & 57 & 490 & $4.86 \%$ \\
\hline Jenna Larson & 1 & 1 & 51 & 128 & 81 & 463 & $4.60 \%$ \\
\hline $\begin{array}{l}\text { Caitlin } \\
\text { Schmidt }\end{array}$ & 1 & 1 & 27 & 65 & 183 & 517 & $5.13 \%$ \\
\hline
\end{tabular}


The name "Kathrine" is more diverse across race and ethnicity in the data with only a $P($ White $\mid$ Name $)=0.389$. This name is more common among Hispanic babies with $\mathrm{P}($ Hispanic $\mid$ Name $)=0.569$, and $\mathrm{P}($ African American $\mid$ Name $)=0.041$.

The name of each prospective student is exposed to subjects in three different ways: through the email address, in the e-mail signature, and in the "from" heading in their inbox. Prospective students are assigned g-mail addresses of the form, firstname.lastname.XXX@gmail.com, where XXX is a three digit number unique to each name.

In addition to race and gender, the experiment varies student quality, represented in three types. The first type of quality, referred to in the design as " $\mathrm{HH}^{\prime}$, has a formal greeting, friendly tone, proper grammar, and proper valediction; it also offers information about the prospective student's GPA and SAT score. The second type of quality, labeled "LH", has an informal greeting, spelling and grammar mistakes, and no valediction, but includes GPA and SAT information drawn from the same distribution as the $\mathrm{HH}$ quality correspondence. The third type of quality, labeled "LL", has the same text as the $\mathrm{LH}$ inquiries, but does not include GPA or SAT information. Within each type, there are four different email templates, two that ask general questions about parking and two that ask general questions about living on campus. Subjects receive the same set of questions across e-mail types; however, the

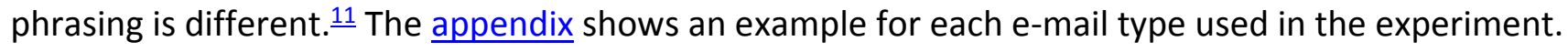

All grade point and SAT information included in e-mail inquiries is randomly assigned. Each $\mathrm{HH}$ and $\mathrm{LH}$ type e-mail is assigned a GPA from a uniform distribution between 3.22 and 3.42. The GPA distribution is centered on the mean GPA for high school students taking the SAT in 2009 (College Board, 2009). Each $\mathrm{HH}$ and LH e-mail is assigned an SAT score from a uniform distribution between 1500 and 1600, representing the median and 60th percentile of SAT scores (scores include critical reading, mathematics, and writing) for college bound test takers in 2009 (College Board, 2009).

The e-mail type (within quality group) is also randomly assigned, but without replacement for a given counselor. Random assignment without replacement of e-mail type ensures that a counselor will not receive exactly the same e-mail text from both inquiries in the experiment. As shown in Table 1, the order of sending e-mails to counselors varies (and is randomly assigned) so that the full experiment includes the same number of inquiries with whites and African Americans sending the first e-mail, and approximately the same number of males and females sending the first inquiry due to random assignment.

To prevent exposing the experiment to counselors, first and second inquiries are sent one-week apart. The pair of e-mails sent to any one counselor always goes out on the same day of the week, Monday, Wednesday, or Friday, one week apart. All e-mails are sent between 1 and 4 p.m., Eastern Time between September 1 and November 19. The timeframe is set before most applications for admission in the following fall are due. In informal discussions with admissions counselors, they suggested this time of year is typically when they get most inquiries from high school students with application questions. Counselors I spoke with suggested they receive as many as 300 e-mails per day from interested high school students. Although anecdotal, this demonstrates that e-mail correspondence is an important means for high school students to acquire information about a particular school. I am unaware of any representative statistics on communication between potential students and admissions counselors 
The potential subject pool for the experiment comes from the universe of college admissions counselors at schools listed in U.S. News and World Report in 2010. The experiment includes the full list of schools classified under each sub-type- National, Liberal Arts, Masters (by region), and Baccalaureate (by region) to compile a list of admissions counselors at each institution. ${ }^{12}$ Table 3 shows basic information about the 1294 schools listed in U.S. News and World Report from which the sample of counselors is drawn. About $40 \%$ of schools are classified as Regional Masters institutions, while the National, Liberal Arts, and Regional Baccalaureate classifications make up about $20 \%$ of schools each. Liberal Arts schools are the most expensive and have the lowest acceptance rates, while having among the smallest enrollments.

Table 3. Summary statistics for schools in sample.

\begin{tabular}{|c|c|c|c|c|c|}
\hline & $\mathbf{N}$ & Tuition & Enrollment & Acceptance Rate & African American Enrollment \\
\hline \multirow[t]{2}{*}{ Full Sample } & 1294 & 21,752 & 7451 & 65.88 & 0.10612 \\
\hline & & (8400) & (9178) & $(18.42)$ & $(0.1549)$ \\
\hline \multirow[t]{2}{*}{ National } & 252 & 24,217 & 18,842 & 61.29 & 0.1042 \\
\hline & & (8592) & $(12,046)$ & $(20.71)$ & $(0.1351)$ \\
\hline \multirow[t]{2}{*}{ Liberal Arts } & 243 & 27,561 & 2121 & 59.52 & 0.07189 \\
\hline & & (9511) & (2891) & $(20.40)$ & $(0.1260)$ \\
\hline \multirow[t]{2}{*}{ Regional Masters } & 531 & 19,323 & 6720 & 68.90 & 0.1209 \\
\hline & & (6724) & (5754) & $(15.13)$ & $(0.1648)$ \\
\hline \multirow[t]{2}{*}{ Regional Baccalaureate } & 268 & 18,417 & 1932 & 70.65 & 0.1208 \\
\hline & & (6111) & $(1580)$ & $(17.47)$ & $(0.1816)$ \\
\hline \multirow[t]{2}{*}{ Historically Black } & 66 & 13,621 & 3504 & 54.87 & 0.8655 \\
\hline & & (3831) & (2699) & $(20.18)$ & $(0.2077)$ \\
\hline
\end{tabular}

Notes: Historically Black Colleges are not mutually exclusive from other categories

Data from U.S. News and World Report, 2010.

Most of the schools in the experiment (1003 of the 1294) provide individual counselor information on an admissions web page at the time of data collection. $\frac{13}{}$ For schools with individual counselor information, research assistants manually collect contact information (and a limited amount of other

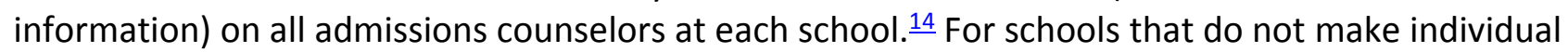
counselor information available, the generic e-mail address for the admissions office or e-mail listed for student inquiries is recorded.

Using the full list of counselors and schools, I randomly chose counselors from each school, without replacement, to send inquiries. $\frac{15}{1}$ To avoid exposing the experiment, e-mails are sent in "rounds". The first round of e-mails is sent to all schools that do not provide individual counselor contact information and one randomly selected counselor per school from schools that provide individual counselor information. The first round of e-mails is sent over two weeks, with within subject types randomly assigned to counselors (within type, template and student name are randomly assigned without replacement, GPA and SAT information are randomly assigned with the potential for an exact match). The second round of e-mails (sent the following week after the first round is complete) is sent to all 
schools that list at least two counselors with contact information, again a counselor is randomly chosen from the set available at each school. Subsequent rounds repeat this random selection process for 6 rounds or 12 weeks of sending e-mails. Later rounds of sending e-mails means the pool of schools shrinks as schools without individual counselor contact information and with fewer than 6 counselors drop out. By the final round, the number of schools in the sample is less than half of the first round.

One point of the experimental design that is not addressed is if counselors practice discrimination, can the source of this bias be determined. While some experimental work has pushed the boundary on identifying differences in behavior that are tied to either taste-based or statistical discrimination, $\underline{16}$ theoretical work by Neilson and Ying (2016) actually shows that taste-based discrimination can lead to subsequent statistical discrimination within an organization. Given the dynamic nature of the interaction between the sources of discrimination and the fact that preferences might be heterogeneous across sub-groups of majority or minority students, we do not attempt to determine if statistical or taste-based discrimination is occurring.

\section{Data}

The experiment sample is 5036 college admissions counselors at 1294 distinct schools. Table 4 offers details on the available information on the sample of subjects. There are 291 schools that do not offer individual counselor contact information; however, because the sample includes more than one counselor from schools that do list counselors individually, the sample includes a direct e-mail address for over $94 \%$ of the subjects in the sample. The prevalence of e-mail availability varies by type of institution, as nearly all Regional Baccalaureate schools make direct e-mail available, while the lowest percent of direct e-mail addresses comes from National schools at $89 \%$.

Table 4. Summary statistics for counselors in sample (standard deviations in parenthesis).

$\begin{array}{cclllll} & \begin{array}{c}\text { Full } \\ \text { Sample }\end{array} & \text { National } & \begin{array}{c}\text { Liberal } \\ \text { Arts }\end{array} & \begin{array}{c}\text { Regional } \\ \text { Masters }\end{array} & \begin{array}{c}\text { Regional } \\ \text { Baccalaureate }\end{array} & \begin{array}{c}\text { Historically } \\ \text { Black }\end{array} \\ \text { Direct E-mail } & 0.936 & 873 & 1086 & 2025 & 1052 & 175 \\ \text { Photo On-Line } & 0.671 & 0.890 & 0.947 & 0.931 & 0.997 & 0.888 \\ \text { Race Known } & 0.591 & 0.544 & 0.732 & 0.666 & 0.761 & 0.265 \\ \text { Race is White } & 0.832 & 0.794 & 0.729 & 0.645 & 0.421 & 0.246 \\ \text { Race is Black } & 0.119 & 0.163 & 0.096 & 0.834 & 0.817 & 0.163 \\ \text { Race is Asian } & 0.020 & 0.014 & 0.021 & 0.020 & 0.113 & 0.037 \\ \text { Ethnicity is Hispanic } & 0.029 & 0.030 & 0.027 & 0.033 & 0.023 & 0.000 \\ \text { Name Known } & 0.946 & 0.916 & 0.938 & 0.963 & 0.978 & 0.000 \\ \text { Gender is Female } & 0.544 & 0.554 & 0.544 & 0.556 & 0.512 & 0.880 \\ \text { Gender is Male } & 0.350 & 0.343 & 0.360 & 0.331 & 0.381 & 0.338 \\ \text { Gender is } & 0.102 & 0.100 & 0.092 & 0.109 & 0.103 & 0.182 \\ \text { Undetermined } & & & & & & \end{array}$

Notes: Historically Black Colleges are not mutually exclusive from other categories. Race Known means are for the full sample of counselors, we are able to identify race for about $87 \%$ (3215) of counselors 
that post a photo. Race means are for the sample of counselors where we know (or can make a reasonable guess) of race and ethnicity. Hispanic is a mutually exclusive category in our characterization of counselor race. Gender Known means indicate the percentage of counselors we have name information on. Gender means (Male, Female, Undetermined) are for the sample of counselors where we have name information (excludes generic e-mail addresses).

Data on admissions counselor characteristics is limited by what schools offer on their web page and what can be reasonably inferred from counselor names and photographs. About $68 \%$ of counselors in the sample have a personal photo available on the school's webpage, and research assistants use this to create information about race. The "Race Known" row of Table 4 indicates the percent of counselors in the sample where the research assistant feels confident about the race of the admissions counselor. Notice that this percent is not equal to the percent that include a photo, as research assistants were instructed to be conservative in assigning a race to subjects. Table 4 also indicates the percent of counselors in the sample by each race or ethnicity from subjects with known race. The vast majority of counselors are white (83\%), African Americans make up about $12 \%$ of the sample, while Asians and Hispanics make up about $2 \%$ each. The racial mix of counselors across type of institution is quite stable, other than for Historically Black colleges, where African Americans make up about $84 \%$ of counselors. $\underline{17}$

Counselor gender is primarily determined by counselor photographs and a research assistant's familiarity with American names. When any question arose regarding the common gender of a given name, the name was entered into the social security database as presented at WolframAlpha.com. If WolframAlpha contained data on only one gender, that gender was assumed. If WolframAlpha contained data on the name use for both genders, and there was a $90 \%$ or greater likelihood for one gender over another, that gender is assigned. For any likelihood less than $90 \%$ (i.e. more balanced numbers of males and females with a particular first name) gender is reported as undetermined. The Name Known row in Table 4 shows that first names are identified for about $95 \%$ of the e-mail addresses in the sample. For counselors whose name is known, about 54\% are female names, while $35 \%$ are male, and $10 \%$ are undetermined. These percentages are quite stable across institution types, with the exception of more undetermined names of counselors at historically black colleges.

Table 5 summarizes the aggregate response data from the experiment. Overall, $72.3 \%$ of the 10,072 emails in the experiment receive a response within 80 days. $\underline{18}$ There is not a directly comparable study to gauge this response rate against, but this response rate is substantially higher than the Bertrand and Mullainathan (2004) resume experiment (6-10\% depending on race), and at the high-end of housing market studies using e-mail correspondence to contact landlords (21-73\% depending on race). For counselors that respond to e-mails, the average delay in responding is $58.5 \mathrm{~h}$, and the average length of a response is 685.5 characters.

Table 5. Response summary.

$\begin{array}{lllll} & \begin{array}{c}\text { Number of E- } \\ \text { mails }\end{array} & \begin{array}{c}\text { Overall Response } \\ \text { Rate }\end{array} & \begin{array}{c}\text { Average Time to } \\ \text { Respond (hours) }\end{array} & \begin{array}{c}\text { Average Length } \\ \text { (characters) }\end{array} \\ \begin{array}{l}\text { Full Sample } \\ \text { School Category }\end{array} & 10,072 & 0.723 & 58.51 & 685.54 \\ \text { National } & 1746 & 0.751 & 57.95 & 784.76 \\ \text { Liberal Arts } & 2172 & 0.692 & 51.91 & 621.05\end{array}$




\begin{tabular}{|c|c|c|c|c|}
\hline & $\begin{array}{l}\text { Number of E- } \\
\text { mails }\end{array}$ & $\begin{array}{l}\text { Overall Response } \\
\text { Rate }\end{array}$ & $\begin{array}{l}\text { Average Time to } \\
\text { Respond (hours) }\end{array}$ & \\
\hline Regional Masters & 4050 & 0.731 & 62.28 & 677.11 \\
\hline Regional Baccalaureate & 2104 & 0.716 & 58.19 & 686.04 \\
\hline \multicolumn{5}{|l|}{ Counselor Race } \\
\hline White & 4956 & 0.753 & 54.45 & 732.26 \\
\hline Black & 706 & 0.632 & 82.47 & 570.73 \\
\hline Asian & 118 & 0.780 & 59.31 & 808.86 \\
\hline Hispanic & 174 & 0.603 & 83.93 & 615.86 \\
\hline $\begin{array}{l}\text { Undetermined (photo } \\
\text { available) }\end{array}$ & 846 & 0.721 & 63.65 & 705.85 \\
\hline Race Unknown (no photo) & 3272 & 0.702 & 57.9 & 677.34 \\
\hline
\end{tabular}

There are some differences in response across school types and counselor race. Counselors at liberal arts schools are least likely to respond, while those at national universities are most likely to respond. When they respond, counselors at liberal arts schools respond fastest, but send the shortest correspondence. Counselors at regional masters schools respond slowest and those at national universities sent the longest correspondence. There are large differences in response rates across race of counselor, with white and Asian counselors more likely to respond than African Americans and Hispanics. Whites and Asians also respond faster, and send longer correspondence than their African American and Hispanic counterparts. The experiment is not designed to determine why counselors with different backgrounds respond differently.

\section{Results}

\section{Response vs. non-response}

Table 6 shows the results of the response/non-response decision by counselors across student race, gender, and quality types $\underline{19}$ for the full sample of counselors and broken down by institution type. The full sample results show that college admission counselors do not treat African American and white potential students differently in terms of whether or not they respond to an inquiry. $\underline{20}$ The response rate is within a half percentage point, and the differential is not statistically distinguishable from zero. The experiment produces results that suggest female students are more likely to receive a response than male students- a difference in response rate of $1.67 \%$, with a $p$-value of 0.06 using a standard test, and a $p$-value of 0.09 clustering standard errors at the institution level. Additionally, there is no distinguishable difference in responding or not by the quality type of e-mails in the experiment. $\underline{21}$

Table 6. Counselor response/non-response by race, gender, and quality. 
Race

Gender

E-mail Quality

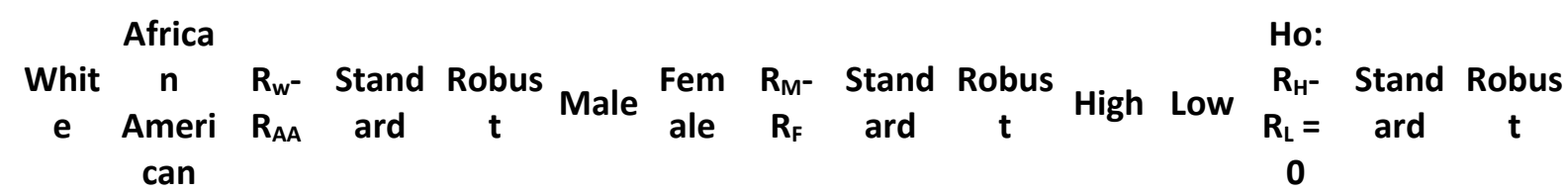

Full $\quad 72.572 .06 \quad 0.46 \quad p=0.6 p=0.571 .473 .1 \quad-1.6 \quad p=0.0 p=0.072 .471 .9 \quad 0.54 \quad p=0.6 p=0.6$

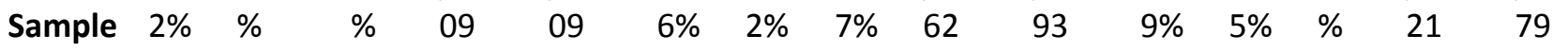

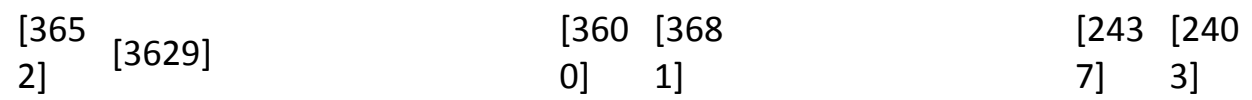

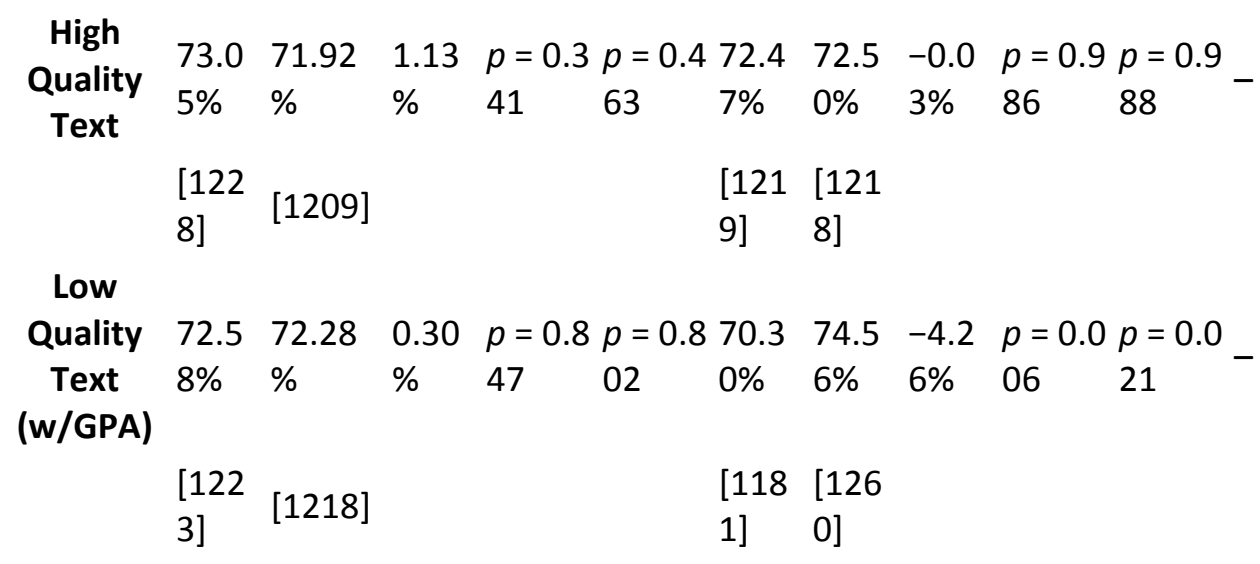

Low

Quality $71.971 .98-0.0 \quad p=0.9 p=0.971 .6 \quad 72.3 \quad-0.7 \quad p=0.6 p=0.7$

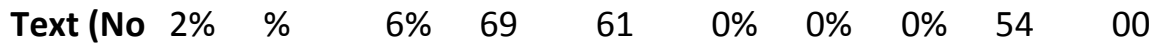

GPA)

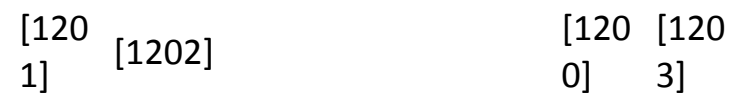

Type of Institution

\begin{tabular}{|c|c|c|c|c|c|c|c|c|c|c|c|c|c|c|c|}
\hline \multirow{2}{*}{ National } & 73.8 & 76.40 & -2.5 & $p=0.2$ & $p=0.1$ & 74.1 & 76.2 & -2.1 & $p=0.2$ & $p=0.3$ & 33.7 & 77.8 & -4.1 & $p=0.0$ & $p=0.1$ \\
\hline & $8 \%$ & $\%$ & $2 \%$ & 22 & 01 & $3 \%$ & $8 \%$ & $4 \%$ & 86 & 54 & $3 \%$ & $7 \%$ & $5 \%$ & 84 & 42 \\
\hline & \multicolumn{5}{|c|}{ [645] [667] } & \multicolumn{5}{|c|}{ [685] [627] } & \multicolumn{5}{|c|}{ [435] [447] } \\
\hline \multirow{3}{*}{$\begin{array}{l}\text { Liberal } \\
\text { Arts }\end{array}$} & 69.3 & 69.06 & 0.28 & $p=0.8$ & $p=0.8$ & 68.5 & 69.9 & -1.3 & $p=0.4$ & $p=0.5$ & 69.2 & 67.7 & 1.49 & \multicolumn{2}{|c|}{$p=0.5 p=0.6$} \\
\hline & $4 \%$ & $\%$ & $\%$ & 89 & 56 & $1 \%$ & $1 \%$ & $9 \%$ & 82 & 47 & $2 \%$ & $3 \%$ & $\%$ & 44 & 25 \\
\hline & \multicolumn{5}{|c|}{ [753] [750] } & \multicolumn{5}{|c|}{ [755] [748] } & \multicolumn{5}{|c|}{ [479] [508] } \\
\hline \multirow{3}{*}{$\begin{array}{l}\text { Regional } \\
\text { Masters }\end{array}$} & 73.4 & 72.74 & 0.69 & $p=0.6$ & $p=0.5$ & 71.9 & 74.1 & -2.2 & $p=0.1$ & $p=0.1$ & 72.9 & 72.4 & 0.47 & \multicolumn{2}{|c|}{$p=0.7 p=0.8$} \\
\hline & $3 \%$ & $\%$ & $\%$ & 20 & 31 & $2 \%$ & $9 \%$ & $7 \%$ & 04 & 65 & $2 \%$ & $5 \%$ & $\%$ & 85 & 10 \\
\hline & $\begin{array}{l}{[148} \\
7]\end{array}$ & [1473] & & & & $\begin{array}{l}{[141} \\
1]\end{array}$ & $\begin{array}{l}{[154} \\
9]\end{array}$ & & & & [999] & [952] & & & \\
\hline \multirow{3}{*}{$\begin{array}{l}\text { Regional } \\
\text { Baccalaur } \\
\text { eate }\end{array}$} & 72.9 & 70.25 & 2.66 & $p=0.1$ & $p=0.0$ & 71.3 & 71.8 & -0.4 & $p=0.8$ & $p=0.8$ & 373.8 & 70.6 & 3.15 & \multicolumn{2}{|c|}{$p=0.1 p=0.2$} \\
\hline & $1 \%$ & $\%$ & $\%$ & 76 & 84 & $3 \%$ & $2 \%$ & $9 \%$ & 04 & 27 & $0 \%$ & $6 \%$ & $\%$ & 87 & 93 \\
\hline & [767 & 39] & & & & [749] & [757] & & & & [524] & {$[496$} & & & \\
\hline
\end{tabular}

Notes: [] indicates number of e-mails that received a reply. Standard $p$-values from $t$-tests of difference in proportions between groups. Robust $p$-values for race results are from McNemar tests which account for the within subjects or paired nature of these data. $p$-values from McNemar tests are equivalent to regression based tests without controls that cluster standard errors at the counselor 
level. Robust $p$-values for gender and quality results account for the within institution correlation that may exist across counselors at the same institution, they cluster standard errors at the institution level.

Table 6 also provides results of discrimination tests between white and African American, and male and female students across quality types. These results reveal that there are not strong differences between the full sample results (pooling quality) and results that separately estimate racial differences for each quality type. There is only a slight exception, that among the high quality e-mail types, white names are slightly preferred in terms of magnitude (1.13 percentage points higher response rate), but this result is not statistically different that zero. For male-female tests across quality, I find that the gap between genders is driven by low-quality inquiries (where students report GPA and SAT information). Females among that quality tier have a 4.26 percentage point higher response rate than malesstatistically significant at the one-percent level. No other quality tier reveals a statistically meaningful result.

There is additional heterogeneity in response differences across institution types. The starkest difference is the finding of substantial discrimination against African Americans for the Regional Baccalaureate category of institutions, a difference of 2.66 percentage points in response rate, with a $p$-value of 0.0837 . In the full sample, this difference is offset by African Americans being favored at National institutions, where they have a 2.5 percentage point higher response rate than white students $(p=0.1011)$. The estimated gender bias toward females observed in the full sample is also present across institution types, and is larger in magnitude in some cases, but never achieves the statistical precision of the full sample results, due to smaller sample sizes. The experiment does uncover some differences in response by quality type across institution, the most noticeable is that low quality students are actually favored at National institutions, with over a 4 percentage point difference in response, $p$-value of 0.0989 .

\section{Heterogeneity by counselor and institution characteristics}

To further examine the potential for heterogeneity in response by characteristics of the sample, I estimate Probit regressions that examine the propensity for a counselor to respond to an inquiry as a function of the experimental stimulus group (African American or Female) and various known characteristics of the counselor or institution. The Probit regressions take the following form:

\section{$(1) \varepsilon$}

Where Group indicates either African American or Female, and Characteristic is a measurable difference observed among either counselors or institutions in the experiment. I estimate (1) for the several characteristics that measure gender and race of counselor and quality or demographics of the institution where the counselor is employed.

Table 7 shows the results of estimating Eq. (1) separately across the range of counselor and institution characteristics, and displays results in terms of the marginal effect. The most striking result is that counselors that share the same race with potential students have a $16.4 \%$ lower likelihood of responding to African American students, a result that is statistically significant at the one-percent level. $\underline{22}$ This result holds even after controlling for the fact that African American counselors are less likely to respond to either race student in the experiment, although the magnitude is only a $7 \%$ 
difference between races. The Probit results also reveal that institutions with lower quality are increasingly likely to respond to African Americans in the experiment, although the magnitude of the difference is small (an increase of less than $1 \%$ for a ranking that is 100 places worse). $\underline{\underline{23}}$

Table 7. Probit results for response/non-response (all coefficients are marginal effects).

\begin{tabular}{|c|c|c|c|}
\hline & Characteristi & Characteristi & Characteristic*Female \\
\hline African American & 0.0105 & & 0.0145 \\
\hline & $(0.0149)$ & & $(0.0176)$ \\
\hline Female & $0.0266 * *$ & 0.0145 & \\
\hline & $(0.0129)$ & $(0.0176)$ & \\
\hline Counselor appears African American & $-0.0547 * *$ & 0.0210 & 0.0125 \\
\hline & $(0.0264)$ & $(0.0323)$ & $(0.0328)$ \\
\hline Counselor and student same gender & -0.0095 & 0.0022 & $0.0541 * * *$ \\
\hline & $(0.0134)$ & $(0.0180)$ & $(0.0173)$ \\
\hline Counselor and Student Same Race ${ }^{a}$ & $0.0329 *$ & $-0.1642 * * *$ & 0.0053 \\
\hline & $(0.0183)$ & $(0.0315)$ & $(0.0199)$ \\
\hline Institution Enrollment (thousands) & -0.0008 & 0.0011 & -0.0013 \\
\hline & $(0.001)$ & $(0.0011)$ & $(0.0011)$ \\
\hline Institution Acceptance Rate & 0.0002 & -0.0433 & 0.0211 \\
\hline & $(0.0004)$ & $(0.0510)$ & $(0.0511)$ \\
\hline Institution Tuition (thousands) & -0.0007 & -0.0046 & $0.0022 * *$ \\
\hline & $(0.0091)$ & $(0.0011)$ & $(0.0011)$ \\
\hline Institution Quality (U.S. News Rank) $\underline{\underline{b}}$ & $-0.0008 * * *$ & $0.0008 * *$ & -0.0004 \\
\hline & $(0.0002)$ & $(0.0004)$ & $(0.0003)$ \\
\hline Percent African Americans Enrolled & $-0.0020 * * *$ & -0.0000 & -0.0009 \\
\hline & $(0.0004)$ & $(0.0006)$ & $(0.0006)$ \\
\hline
\end{tabular}

Standard errors in parentheses

$* * * p<0.01, * * p<0.05, * p<0.1$

a

The result that counselors of the same race are less likely to reply to African American inquiries holds even when controlling for the lower response rate of counselors who are African American. The results controlling for counselor race suggest the magnitude of this effect is smaller- suggesting the effect is about a $7 \%$ reduction in probability of response.

b

U.S. News Rank is equal to one for the top quality institution within a category and counts up as quality decreases. 
The results by characteristics of counselors and institutions also reveal that female counselors are more likely to respond to female students, by $5.4 \%$, than they are to male students. I also find a positive correlation between the tuition at an institution and the response to females, but the effect is quite small- a $\$ 10,000$ increase in annual tuition results in less than a one percent increase in the response difference between males and females.

\section{Content of response}

The e-mail record provided by the correspondence set-up allows for a more in-depth examination of response by admissions counselors. Following Hanson, Hawley and Taylor (2011) in examining landlord responses to potential housing tenants, searching the text of e-mail responses indicates what type of response the counselor is sending, rather than just if they have responded or not. It may be that while counselors respond to all groups, the content of the response looks quite different.

The most basic way to examine the text of response is to compare the time it takes a counselor to respond and the length of the response. I also implement keyword searches to create indicator variables that define the type of response according to six categories: Polite, Positive, Questioning, Informative, Invite Further Contact, and Academic. The categories are intended to capture a number of ways that the e-mail response may be different that could matter to potential student's interest in attending the University. Definitions of keywords contained for each category are given in the footnotes of Table 8. This dimension of response is important because the counselor response rate is fairly high, but counselors can choose to give more less information, be encouraging or not, or change how they treat the student and that treatment may encourage/discourage an application. Content measures effectively measure dimensions of counselor effort with potential students.

Table 8. Counselor response time, length of e-mail, and content of response by race, gender, and quality.

\begin{tabular}{|c|c|c|c|c|c|c|c|c|c|}
\hline & \multicolumn{3}{|c|}{ Race } & \multicolumn{3}{|c|}{ Gender } & \multicolumn{3}{|c|}{ E-mail Quality } \\
\hline & White & $\begin{array}{c}\text { African } \\
\text { American }\end{array}$ & $\begin{array}{l}\text { Ho: Rw- } \\
\text { RAA = } 0\end{array}$ & Male & Female & $\begin{array}{c}\text { Ho: RM- } \\
\text { RF }=0\end{array}$ & High & Low & $\begin{array}{c}\text { Ho: } R H- \\
\text { RL }=0\end{array}$ \\
\hline \multirow[t]{2}{*}{$\begin{array}{l}\text { Time to } \\
\text { Respond }\end{array}$} & 58.96 & 58.07 & 0.89 & 58.00 & 59.02 & -1.02 & 67.31 & 47.97 & 19.33 \\
\hline & $(139.84)$ & $(130.94)$ & $p=0.9998$ & $(135.68)$ & $(135.29)$ & $p=0.7486$ & $(143.99)$ & $(117.89)$ & $p=0.0000$ \\
\hline \multirow[t]{2}{*}{$\begin{array}{l}\text { Length of E- } \\
\text { mail }\end{array}$} & 690.27 & 680.83 & 9.44 & 673.77 & 697.34 & -23.56 & 846.87 & 535.35 & 311.53 \\
\hline & $(779.50)$ & $(769.86)$ & $p=0.5411$ & $(761.37)$ & )$(787$ & $p=0.1269$ & $(877.91)$ & $(646.65)$ & $p=0.0000$ \\
\hline \multicolumn{10}{|c|}{ Content of E-mail Response } \\
\hline \multirow[t]{2}{*}{ Polite } & $52.80 \%$ & $52.07 \%$ & $0.73 \%$ & $51.07 \%$ & $53.79 \%$ & $-2.72 \%$ & $57.73 \%$ & $48.38 \%$ & $9.35 \%$ \\
\hline & [2659] & [2622] & $p=0.3304$ & [2573] & [2708] & $p=0.0062$ & [1941] & [1616] & $p=0.0000$ \\
\hline \multirow[t]{2}{*}{ Positive } & $48.13 \%$ & $47.04 \%$ & $1.09 \%$ & $45.71 \%$ & $49.46 \%$ & $-3.75 \%$ & $53.93 \%$ & $40.60 \%$ & $13.33 \%$ \\
\hline & [2424] & [2369] & $p=0.1574$ & [2303] & [2490] & $p=0.0002$ & [1813] & [1356] & $p=0.0000$ \\
\hline \multirow[t]{2}{*}{ Questioning } & $54.65 \%$ & $54.29 \%$ & $0.36 \%$ & $53.79 \%$ & $55.15 \%$ & $-1.35 \%$ & $62.14 \%$ & $44.64 \%$ & $17.49 \%$ \\
\hline & [2752] & [2734] & $p=0.6498$ & [2710] & [2776] & $p=0.1725$ & [2089] & [1491] & $p=0.0000$ \\
\hline Informative & $62.07 \%$ & $61.52 \%$ & $0.56 \%$ & $61.16 \%$ & $62.44 \%$ & $-1.28 \%$ & $63.68 \%$ & $61.26 \%$ & $2.42 \%$ \\
\hline
\end{tabular}


Race

\begin{tabular}{|c|c|c|c|c|c|c|c|c|c|}
\hline & White & $\begin{array}{c}\text { African } \\
\text { American }\end{array}$ & $\begin{array}{l}\text { Ho: } R w- \\
\text { RAA }=0\end{array}$ & Male & Female & $\begin{array}{c}\text { Ho: RM- } \\
\text { RF = } 0\end{array}$ & High & Low & $\begin{array}{c}\text { Ho: } R H- \\
\text { RL }=0\end{array}$ \\
\hline & [3126] & [3098] & $p=0.4664$ & [3081] & [3143] & $p=0.1861$ & [2141] & [2046] & $p=0.0404$ \\
\hline \multirow[t]{2}{*}{$\begin{array}{l}\text { Invite Further } \\
\text { Contact }\end{array}$} & $60.41 \%$ & $59.31 \%$ & $1.09 \%$ & $59.17 \%$ & $60.55 \%$ & $-1.38 \%$ & $63.15 \%$ & $56.95 \%$ & $6.20 \%$ \\
\hline & [3042] & [2987] & $p=0.1623$ & [2981] & [3048] & $p=0.1584$ & [2123] & [1902] & $p=0.0000$ \\
\hline \multirow[t]{2}{*}{ Academic } & $36.30 \%$ & $35.80 \%$ & $0.50 \%$ & $35.67 \%$ & $36.43 \%$ & $-0.76 \%$ & $52.08 \%$ & $12.19 \%$ & $39.90 \%$ \\
\hline & [1828] & [1803] & $p=0.4919$ & [1797] & [1834] & $p=0.4250$ & [1751] & [407] & $p=0.0000$ \\
\hline
\end{tabular}

Notes: [] indicates number of e-mails that received a reply, () indicates standard deviation. $p$-values for race results testing time to respond and length of e-mail are from paired difference in means tests, difference in percent of counselors are from McNemar tests which account for the within subjects or paired nature of these data. $p$-values for gender and e-mail quality results testing time to respond and length of e-mail are from standard difference in means tests, difference in percent of counselors are from standard difference in proportions tests.

"Polite" indicates that the e-mail response included one of the following words or phrases: hello, dear, hi, hey there, thank(s), sincerely, please.

"Positive" indicates that the e-mail response included one of the following words or phrases: great, happy, glad, excellent, fabulous, wonderful, good, encourage, excited, look forward, new, wow, welcome.

"Questioning" indicates that the e-mail response included one of the following words or phrases: transcript, high school, rank, math, verbal, include, writing, composite, core, class.

"Informative" indicates that the e-mail response included one of the following words or phrases: park, car, fee, housing, house, apartment, dorm, free, http (web address), www (web address).

"Invite Further Contact" indicates that the e-mail response included one of the following words or phrases: admit, admission, application, apply, campus, visit, please call, call, write.

"Academic" indicates that the e-mail response included one of the following words or phrases: study, program, gpa, sat, scholar, qualified, major, qualify.

Table 8 shows results for differences in the time to respond, length of response, and content of response by race, gender, and quality of applicant. As with the full sample response/non-response results, there is almost no difference in how counselors respond by race of the student. The sign of the difference suggests slight favoritism towards whites (except in speed of response), but the magnitudes are all small, and $p$-values indicate that the results are not statistically distinguishable.

As with the response/non-response results, there are large differences in how counselors respond by student gender, all in favor of female students. The results in Table 8 show that counselors use polite language more often when replying to female inquiries than when replying to males, a difference of 2.7 percentage points, statistically significant at the one percent level. More counselors use positive 
language when replying to females, a difference of 3.75 percentage points and again statistically significant at the one percent level. There are no other statistically meaningful differences across gender, but more counselors use language associated with all of the categories when responding to females. There is also a fairly large, 23.5 character, difference in the average length of response that is close to statistical significance at the ten percent level $(p=0.1269)$.

The last three columns of Table 8 test for differences in how counselors respond to e-mail inquiries of different quality. There are large differences in the time to respond, length of e-mail, and in all keyword search categories between high quality and low quality e-mails. Counselors take about $19 \mathrm{~h}$ and 20 min longer to respond, and write e-mails that are about 311 characters longer when responding to high quality inquiries, both statistically significant at the one percent level. In keyword searches, more counselors use language associated with each of the categories when responding to high quality e-mails. The magnitude of this difference is quite large, up to $39 \%$ of counselors for the academic keyword category.

The large differences in how counselors respond to high and low quality e-mails are suggestive evidence that counselors are sensitive to the content of e-mails in the experiment. This is not direct evidence that counselors interpret the names in the experiment as associated with a particular race and gender before choosing how to reply, but it suggests that at least they are making some decisions in how they respond based on the stimulus in the e-mail inquiry.

\section{Robustness}

The strongest findings from the baseline experiment are that admissions counselors favor female prospective students over males both in response/non-response and in the content of replies, and that counselors at regional baccalaureate institutions favor whites while African Americans are favored among national universities. In this section, I explore how robust the primary findings are to using certain names in the experiment and to inquiring to a generic vs. personal e-mail address.

Using a variety of names to represent race and gender has the advantage of preventing exposure of the experiment, but at the cost of potentially introducing heterogeneity in the intended treatment if names within a race/gender category are viewed differently by subjects. Table 9 shows results for tests of response rate equivalence between each name in the experiment and other names of the same gender and race. There are two African American names, Darnell Robinson and Jamal Washington, which have statistically different response rates than the group of other African American males. Darnell's response rate is statistically higher than other African American male names, while Jamal's is statistically lower. There is one white male name, Brendan Carlson, which has a statistically lower response rate than other white male names. The only other statistically different name is Kathryn Olson, which has a higher response rate than other white females at the $10 \%$ significance level.

Table 9. Tests of equivalence between name and race/gender category.

Response Rate RRname $=$ RRrace/gender, $p$-value

\section{African American Male}

$\begin{array}{lll}\text { Darnell Robinson } & 74.71 \% & \boldsymbol{p}=\mathbf{0 . 0 3 0} \\ \text { Dwayne Williams } & 71.66 \% & p=0.639\end{array}$




\section{Response Rate RRname $=$ RRrace/gender, $p$-value}

$\begin{array}{ccc}\text { Jamal Washington } & 65.98 \% & \boldsymbol{p}=\mathbf{0 . 0 0 8} \\ \text { Kadeem Jackson } & 70.86 \% & p=0.999 \\ \text { Tyrone Smith } & 70.75 \% & p=0.951\end{array}$

African American Female

$\begin{array}{ccc}\text { Asia Robinson } & 71.86 \% & p=0.398 \\ \text { Chantel Smith } & 71.24 \% & p=0.232 \\ \text { Latoya Williams } & 74.12 \% & p=0.635 \\ \text { Ebony Jackson } & 75.35 \% & p=0.237 \\ \text { Shaniqua Washington } & 74.19 \% & p=0.630 \\ \text { White Male } & & \\ \text { Ethan Olson } & 73.90 \% & p=0.292 \\ \text { Dylan Larson } & 74.40 \% & p=0.194 \\ \text { Maxwell Smith } & 70.47 \% & p=0.374 \\ \text { Brendan Carlson } & 68.27 \% & p=0.031 \\ \text { Zachary Schmidt } & 73.42 \% & p=0.462 \\ \text { White Female } & & \\ \text { Erin Carlson } & 73.71 \% & p=0.665 \\ \text { Marissa Smith } & 73.36 \% & p=0.832 \\ \text { Kathryn Olson } & 76.12 \% & p=0.081 \\ \text { Jenna Larson } & 70.41 \% & p=0.167 \\ \text { Caitlin Schmidt } & 71.18 \% & p=0.300\end{array}$

Notes: $p$-value is from difference in proportions $t$-test between each name and all other names of the same race and gender. Bold indicates statistically different at the $5 \%$ level, italics indicates statistically different at the $10 \%$ level.

The inherent heterogeneity of names is further demonstrated in Table 2, which shows that names in the experiment have different levels of popularity nationally. Differences in popularity are unavoidable, as African American's make up a smaller portion of the general population, robustness tests examine how this difference may affect the general findings of the experiment.

Table 10 reproduces the strongest results from the general experiment, using sub-groups of names, and testing using only counselor e-mail addresses that were directly connected to a specific person (excluding all generic inquiry e-mail addresses). In general, the sign and magnitude of racial discrimination is the same as the full sample findings- counselors at National universities favor African Americans, while those at Regional Baccalaureate institutions favor whites. The robustness checks also confirm no difference between races for the full sample of schools. In nearly all cases, however, the race robustness checks produce a result that is not statistically meaningful. The gender robustness checks confirm that females are favored over males by approximately the same magnitude as the full sample results. The robustness checks for the gender result are statistically meaningful, or close, in three of the six robustness checks, with smaller sample sizes in the more restrictive tests reducing precision. 
Table 10. Robustness of primary findings.

\begin{tabular}{|c|c|c|c|c|c|c|}
\hline & $\begin{array}{l}\text { Exclude } \\
\text { Darnell, } \\
\text { Kadeem, } \\
\text { Brendan }\end{array}$ & $\begin{array}{l}\text { Exclude } \\
\text { Darnell, } \\
\text { Kadeem, } \\
\text { Brendan, } \\
\text { Kathryn }\end{array}$ & $\begin{array}{c}\text { Exclude most } \\
\text { popular white, } \\
\text { least popular } \\
\text { African American }\end{array}$ & $\begin{array}{l}\text { Exclude Most Popular } \\
\text { white both gender, } \\
\text { least popular African } \\
\text { American both } \\
\text { gender }\end{array}$ & $\begin{array}{l}\text { Use Only } \\
\text { Smith's }\end{array}$ & $\begin{array}{c}\text { Personal } \\
\text { E-mail } \\
\text { Only }\end{array}$ \\
\hline \multicolumn{7}{|l|}{ Race Results } \\
\hline \multirow[t]{2}{*}{$\begin{array}{l}\text { Full Sample, } H_{0} \text { : } \\
\qquad \mathbf{R}_{\mathbf{w}}-\mathbf{R}_{\mathrm{AA}}=\mathbf{0}\end{array}$} & $1.13 \%$ & $0.77 \%$ & $0.02 \%$ & $0.06 \%$ & $0.90 \%$ & $0.64 \%$ \\
\hline & $p=0.348$ & $p=0.558$ & $p=0.705$ & $p=0.587$ & $p=0.653$ & $p=0.492$ \\
\hline \multirow[t]{2}{*}{ National } & $-1.50 \%$ & $-1.79 \%$ & $-2.64 \%$ & $-2.92 \%$ & $-3.48 \%$ & $-2.57 \%$ \\
\hline & $p=0.321$ & $p=0.478$ & $p=0.071$ & $p=0.116$ & $p=0.450$ & $p=0.248$ \\
\hline \multirow[t]{2}{*}{$\begin{array}{c}\text { Regional } \\
\text { Baccalaureate }\end{array}$} & $2.98 \%$ & $2.85 \%$ & $2.57 \%$ & $2.48 \%$ & $-0.08 \%$ & $2.15 \%$ \\
\hline & $p=0.290$ & $p=0.555$ & $p=0.118$ & $p=0.127$ & $p=0.985$ & $p=0.282$ \\
\hline \multicolumn{7}{|l|}{ Gender Results } \\
\hline \multirow[t]{2}{*}{$\begin{array}{l}\text { Full Sample, } H_{0} \text { : } \\
\mathrm{R}_{\mathrm{M}}-\mathrm{R}_{\mathrm{F}}=0\end{array}$} & $-1.59 \%$ & $-1.27 \%$ & $-1.82 \%$ & $-2.00 \%$ & $-1.66 \%$ & $-2.18 \%$ \\
\hline & $p=0.104$ & $p=0.207$ & $p=0.053$ & $p=0.405$ & $p=0.408$ & $p=0.019$ \\
\hline
\end{tabular}

Notes: $p$-values for Race results are from McNemar tests which account for the within subjects or paired nature of these data, except when using only Smith last names (this test is a standard difference in proportions test). $p$-values for Gender results are from standard difference in proportions test.

\section{Conclusion}

This paper uses a field experiment to explore the potential for differential treatment by college admissions counselors on the basis of race, gender, and student quality. The findings show that counselors do not treat inquiries from African Americans and white potential students differently, and that equal treatment is present along both the response/non-response margin as well as in the content of responses. The findings also show that counselors favor female students over males in the response/non-response decision, and by being more positive and polite in the content of their response. There are also large differences in the text of counselor responses to students of different quality, with higher quality students being treated favorably in every measured response outcome.

These findings suggest, that while there are large differences in college enrollment and completion between whites and African Americans, it does not seem likely that discrimination in the application process contributes to those differences. The findings also suggest that differential treatment by gender in the form of favoring female applicants is occurring by college admissions counselors. While this work does not produce any direct evidence to link differential treatment by gender to application or enrollment decisions, it seems reasonable to conclude that these treatment differences could contribute to increasing costs associated with applying to college for males relative to females, which may exacerbate the existing gender gap in college attendance. 
HH Type E-mail:

Dear Admissions Counselor,

I am interested in finding out more about your school. I've already taken the SAT and scored a [X], and my GPA is a $[Y]$ on a 4 point scale.

Could you please tell me more about what else you require for admission besides grades and SAT scores?

Also, I'm interested to know what student housing is like on your campus.

Thanks in advance for taking the time to reply.

Sincerely,

[NAME]

\section{LH Type E-mail:}

$\mathrm{Hi}$,

I'm looking for collages [sic] and I want to know more about your school. My SAT is [X] and my GPA is $[\mathrm{Y}]$. Is that in the range you need?

Can u tell me what places are their [sic] to live around campus and how that all works to [sic]?

[NAME]

\section{$\underline{\text { LL Type E-mail: }}$}

$\mathrm{Hi}$,

I'm looking for collages [sic] and I want to know more about your school.

Can $u$ tell me what places are their [sic] to live around campus and how that all works to[sic]?

[NAME]

\section{References}

Ahmed, A.M., Hammarstedt, M." Discrimination in the rental housing market: A field experiment on the internet." Journal of Urban Economics, 64 (2) (2008), pp. 362-372. 
Angrist, J., Evans, W. "Schooling and labor market consequences of the 1970 state abortion reforms." Research in Labor Economics, 18 (2000), pp. 75-113.

Arcidiacono, P., Lovenheim, M., Zhu, M. "Affirmative action in undergraduate education." Annual Review of Economics, 7 (2015), pp. 487-518.

Avery, C. "The effects of college counseling on high-achieving, low-income students." National Bureau of Economic Research (2010).

Avery, C., Howell, J., Page, L. "A review of the role of college applications on students' postsecondary outcomes." College Board Research Brief (2014).

Backes, B. "Do affirmative action bans lower minority college enrollment and attainment? Evidence from statewide bans." Journal of Human Resources, 47 (2) (2012), pp. 435-455.

Becker, G. The economics of discrimination. University of Chicago Press, Chicago and London (1957).

Balafoutas, L., Davis, B., Sutter, M. "Affirmative action or just discrimination? A study on the endogenous emergence of quotas." Journal of Economic Behavior and Organization, 127 (2016), pp. 87-98.

Bertrand, M., Hanna, R., Mullainathan, S. "Affirmative action in education: Evidence from engineering college admissions in India." Journal of Public Economics, 94 (2010), pp. 16-29.

Bertrand, M., Mullainathan, S. "Are Emily and Greg more employable than Lakisha and Jamal? A field experiment on labor market discrimination." American Economic Review, 94 (4) (2004), pp. 9911013.

Bound, J., Lovenheim, M., Turner, S. "Why have college completion rates declined? An analysis of changing student preparation and collegiate resources." American Economic Journal: Applied Economics, 2 (3) (2010), pp. 129-157.

Bowen, W., Bok, D. The shape of the river: long-term consequences of considering race in college and university admissions. Princeton University Press, Princeton, New Jersey (1998).

Buchmann, C., DiPrete, T., McDaniel, A. "Gender inequalities in education." Annual Review of Sociology, 34 (2008), pp. 319-337.

Card, D., Lemieux, T. "Going to college to avoid the draft: The unintended legacy of the Vietnam war." American Economic Review, 91 (2) (2001), pp. 97-102.

Carpusor, A., Loges, W. "Rental discrimination and ethnicity in names." Journal of Applied Social Psychology, 36 (4) (2006), pp. 934-952.

Castillo, M., Petrie, R. “Discrimination in the lab: Does information trump appearance?" Games and Economic Behavior, 68 (2010), pp. 50-59. 
Cornwell, C., Mustard, D., Van Parys, J. "Non-cognitive skills and the gender disparities in test scores and teacher assessments." Journal of Human Resources, 48 (1) (2013), pp. 236-264.

College Board. Total Group Profile Report for College Bound Seniors. www.collegeboard.com (2009).

Dougherty, C. "Why are returns to schooling higher for women than for men?" Journal of Human Resources, 40 (4) (2005), pp. 969-988.

Ewens, M., Tomlin, B., Wang, C. "Statistical discrimination or prejudice? A large sample field experiment." Review of Economics and Statistics, 96 (1) (2014), pp. 119-134.

Feld, J., Salamanca, N., Hamermesh, D. “Endophilia or exophobia: Beyond discrimination.” Economic Journal, 126 (2015), pp. 1503-1527.

Fortin, N., Oreopoulos, P., Phipps, S. "Leaving boys behind: Gender disparities in high academic achievement." Journal of Human Resources, 50 (3) (2015), pp. 549-579.

Gaddis, M. "Discrimination in the credential society: An audit study of race and college selectivity in the labor market." Social Forces, 93 (4) (2014), pp. 1451-1479.

Goldin, C., Katz, L., Kuziemko, I. "The homecoming of american college women: The reversal of the college gender gap." Journal of Economic Perspectives, 20 (4) (2006), pp. 133-156.

Hanna, R., Linden, L. "Discrimination in grading." American Economic Journal: Economic Policy, 4 (4) (2012), pp. 146-168.

Hanson, A., Hawley, Z. "Do landlords discriminate in the rental housing market? Evidence from an internet field experiment in US cities." Journal of Urban Economics, 70 (2-3) (2011), pp. 99-114.

Hanson, A., Hawley, Z, Martin, H., Liu, B. "Discrimination in mortgage lending: Evidence from a correspondence experiment." Journal of Urban Economics, 92 (2) (2016), pp. 48-65.

Hanson, A., Hawley, Z., Taylor, A. "Subtle discrimination in the rental housing market: Evidence from email correspondence with landlords." Journal of Housing Economics, 20 (4) (2011), pp. 276-284.

A. Hanson, A., M. Santas, M. "Field experiment tests of discrimination against hispanics in the rental housing market." Southern Economic Journal, 81 (1) (2014), pp. 135-167.

Hinnerich, B., Höglin, E., Johannesson, M. “Discrimination against students with foreign backgrounds: Evidence from grading in Swedish public high schools." Education Economics, 23 (6) (2015), pp. 660-676.

Hinrichs, P. "The effects of affirmative action bans on college enrollment, educational attainment, and the demographic composition of universities." Review of Economics and Statistics, 94 (3) (2012), pp. 712-722. 
Hock, H. "The pill and the college attainment of american women and men." Unpublished Manuscript (2005).

Hoffmann, F., Oreopoulos, P. “A professor like me: The influence of instructor gender on college achievement." Journal of Human Resources, 44 (2) (2009), pp. 479-494.

Holland, M. "Navigating the road to college: Race and class variation in the college application process." Sociology Compass, 8 (10) (2014), pp. 1191-1205.

Holzer, H., Ludwig, J. "Measuring discrimination in education: Are methodologies from labor and markets useful?" Teachers College Record, 105 (6) (2003), pp. 1147-1178.

Hoxby, C., Avery, C. "The missing 'one-offs': The hidden supply of high-achieving, low-income students." Brookings papers on economic activity, Spring (2013), pp. 1-65.

Hurtado, S., Inkelas, K.K., Briggs, C., Rhee B.-S. "Differences in college access and choice among racial/ethnic groups: Identifying continuing barriers." Research in Higher Education, 38 (1) (1997), pp. 43-75.

Kapor, A. "Distributional effects of race-blind affirmative action." (2015) Unpublished Manuscript.

Light, A., Strayer, W. "From bakke to hopwood: Does race affect college attendance and completion?" Review of Economics and Statistics, 84 (1) (2002), pp. 34-44.

List, J. "The nature and extent of discrimination in the marketplace: Evidence from the field." Quarterly Journal of Economics, 119 (1) (2004), pp. 49-89.

Long, M. "Race and college admissions: An alternative to affirmative action?" Review of Economics and Statistics, 86 (4) (2004), pp. 1020-1033.

Neumark, David with the assistance of Roy Bank and Kyle Van Nort. "Sex discrimination in restaurant hiring: An audit study." Quarterly Journal of Economics, 111 (3) (1996), pp. 915-941.

Nielson, W., Ying, S. "From taste-based to statistical discrimination." Journal of Economic Behavior and Organization, 129 (2016), pp. 116-128.

Nunley, J., Owens, M., Stephen Howard, R. "The effects of information and competition on racial discrimination: Evidence from a field experiment." Journal of Economic Behavior and Organization, 80 (2011), pp. 670-679.

Phelps, E., "The statistical theory of racism and sexism." American Economic Review, 62 (1972), pp. 659-661.

Riach, P.A., Rich, J. "Field Experiments of discrimination in the market place." Economic Journal, 112 (2002), pp. 480-518. 
Ross, T., Kena, G., Rathbun, A., Kewal Ramani, A., Zhang, J., Kristapovich, P., et al. "Higher education: gaps in access and persistence study." National Center for Education Statistics, U.S. Department of Education (2012).

Slonim, R., Guillen, P. “Gender selection discrimination: Evidence from a trust game." Journal of Economic Behavior and Organization, 76 (2010), pp. 385-405.

Smith, J., Hurwitz, M., Howell, J. "Screening mechanisms and student responses in the college market." Economics of Education Review, 44 (2014), pp. 17-28.

Smith, J. "The effect of college applications on enrollment." The B.E. Journal of Economic Analysis and Policy, 14 (1) (2014), pp. 151-188.

Sprietsma, M. "Discrimination in grading: Experimental evidence from primary school teachers." Empirical Economics, 45 (2011), pp. 523-538.

望 I thank Kurt Schnier and Spencer Banzhaf for help in conceiving this idea and designing the experiment, and seminar participants at the University of Illinois - Chicago for comments on an earlier draft. Hal Martin and Michael Santas provided outstanding research assistance in assembling a subject pool and implementing the experiment. This research was approved by an Institutional Review Board. Any errors are my own.

1 Summary statistics on enrollment, completion, and attendance are reported in Table 33-1 of the National Center for Education Statistics August 2012 report titled, "Higher Education: Gaps in Access and Persistence Study" (Ross et al., 2012). The underlying data for the table are taken from the 2010 American Community Survey.

2 Summary statistics on completion rates are reported in Table 42-1 of the National Center for Education Statistics August 2012 report titled, "Higher Education: Gaps in Access and Persistence Study" (Ross et al., 2012). The underlying data for the table are taken from the U.S. Department of Education Integrated Postsecondary Education Data System Graduation Rates component.

3 Empirical work by Light and Strayer (2002) shows "observationally equivalent" minorities are actually more likely than whites to attend and graduate from college- suggesting that differences in actual attendance and graduation rates reflect unobservable differences in characteristics between groups. Bowen and Bok (1998) present evidence that suggests, among a group of "academically selective" colleges, that African Americans with equivalent SAT scores are as much as three times as likely to gain admission as whites with equivalent scores.

4 See Hurtado et al. (1997) for a study using observational data to explore the factors that contribute to differences in college access and choice between whites and minorities. There is a vast literature on the factors that affect college attendance and completion differences between male and female students, examples include avoiding war (Card and Lemieux, 2001), the introduction of the pill ( school characteristics such as student-faculty ratios (Bound et al., 2010), a divergence in future aspirations that includes graduate school attendance (Fortin et al., 2015), the influence of 
instructor gender (Hoffmann and Oreopoulos, 2009), less favorable grading of male students linked to non-cognitive skill differences (Cornwell et al., 2013), and the disproportionate return to schooling for women (Dougherty, 2005), for a recent review of this literature see Buchmann et al. (2008).

5 See Long (2004), Bertrand et al. (2010), Backes (2012), Hinrichs (2012), and Kapor (2015) for recent studies on how affirmative action and race-blind admissions policies affect college enrollment and degree attainment. Arcidiacono et al. (2015) provide a thorough review of affirmative action policies and the extensive literature examining their impact on a variety of outcomes. See Balafoutas et al. (2016) for an experimental investigation into how affirmative action rules emerge and relate to discrimination.

6 Neumark examines gender discrimination in hiring using a combination of the in-person and correspondence audit method. Actors are used to drop off resumes at restaurants, but also have personal interactions with employers.

7 See Gaddis (2014) for an experiment that examines the interaction between race and a college degree in the labor market. The experiment finds that the return to an education from an elite university for an African American job seeker is equivalent to a less selective university degree for a white candidate.

8 The Feld et al. experiment offers a unique opportunity to explore if subjects are treating students that share a common characteristic favorably, or if subjects are treating students that are different unfavorably. This work suggests that favoring like-kind dominates mistreating those who are different.

9 Surnames are chosen from among the race specific names in Bertrand and Mullainathan (2004), with the exception of "Smith" which was chosen for one name in all race-gender in order to perform robustness checks where only student first name differs.

10 The New York Department of Health and Human Hygiene does not report counts of births were less than five occurrences in a race/gender occur, so these probabilities may not be exactly equal to one.

$\underline{11}$ I consulted an admissions counselor to help me choose realistic information, language, tone, and grammar in e-mail inquiries. To avoid the potential for exposing the experiment the consulting counselor's University was not included in the experimental sample.

$\underline{12}$ Research assistants complied the list of counselors and contact information between March and August, as close to the start of the experiment as possible. It is possible that counselors vacated their position, changed e-mail addresses or were otherwise unable to reply to e-mail due to the lag between collecting counselor information and starting the experiment. This lag is unavoidable due to the time intensive nature of collecting counselor contact information; randomization in the design prevents this from biasing results on differential treatment, although it may lower overall response rates. 
$\underline{13}$ Of the 291 schools that do not list individual counselor contact information 26 are Regional Baccalaureate, 47 are Liberal Arts, 128 are Regional Masters, and 90 are National.

$\underline{14}$ For convenience, I refer to subjects as admissions counselors. This is the most common title; however, some subjects are listed under other titles such as "Admissions Staff", "Enrollment Specialist", "Admissions Associate", "Admissions Advisor", "Assistant to Admissions Director", "Multi-Cultural Recruitment Coordinator", "Admissions Representative", "Recruitment Specialist", and "Enrollment Services Counselor" to name a few. Regardless of the official title, these individuals are included as potential subjects in the experiment because they were listed as a resource for student inquiries by the university that employs them.

15 The initial data collection effort yielded contact information on 7045 counselors (including generic admissions contacts), of these 5036 were randomly selected as subjects in the experiment.

$\underline{16}$ List (2004), Castillo and Petrie (2010), Slonim and Guillen (2010) and Ewens et al. (2014) are examples of experimental work that attempt to distinguish between taste-based and statistical discrimination.

17 Historically Black Colleges is not a mutually exclusive category, U.S. News and World Report identifies the colleges in this group.

$\underline{18}$ Response is limited to the first 80 days after sending e-mails for the practical purpose of uploading response data all at one time. To treat all rounds the same, 80 days is allowed after each e-mail, regardless of round, before it is considered a non-response. $99 \%$ of e-mails that receive a response do so within 27 days, $75 \%$ of e-mails that receive a response do so within 3 days.

19 All quality tests are between the $\mathrm{HH}$ quality e-mails that are written in proper English and include GPA and SAT information, and the LL quality e-mails that are poorly written and do not include GPA or SAT information.

$\underline{20}$ A response is considered a response only if it is determined to be genuinely made by a human. All automatic replies are coded as a non-response for all tests of discrimination. About $10 \%$ of replies were deemed not genuinely made by a human.

$\underline{21}$ Because the experiment uses multiple counselors at the same institution, it is possible that the experiment is exposed to subjects by the sequence of sending e-mails. The design of the experiment, including the multiple text format of inquiries, and multiple names used work to combat exposure, and I find no anecdotal evidence that counselors indicated they were aware that the e-mails were not genuine. I do find, however, that the order within an institution has a small negative correlation with responding to African American students. The magnitude of this correlation suggests that sending the inquiry one counselor later is correlated with a counselor being one-percent less likely to respond to an African American student, but this correlation is not statistically meaningful in a regression model of response. I find no correlation between order of sending within an institution and response to female students. 
$\underline{22}$ The result that same race counselors are less likely to respond to African American students is not sensitive to excluding counselors from Historically Black Colleges (HBC). Excluding the 175 counselors at the $66 \mathrm{HBC}$ in the sample only reduces the point estimates on the same race coefficient slightly, and does not appreciably change statistical significance of these results.

$\underline{23}$ Testing for a differential ranking effect within institutional category (National, Liberal Arts, Regional) yields similar magnitude results for African American students, but these results lose statistical significance, possibly due to the lower number of observations. Testing for a differential ranking effect within institutional category for female students yields a slightly more negative, but still statistically insignificant, effect of lower rankings for Regional and National institutions than for Liberal Arts colleges. 